\title{
PENERAPAN METODE PROBLEM BASED LEARNING DALAM MENINGKATKAN KETERAMPILAN BERPIKIR KRITIS SISWA PADA MATA PELAJARAN ILMU PENGETAHUAN SOSIAL
}

\author{
Cicilia Melinda', Ilham Rahmawati ${ }^{2}$ \\ 1,2 Universitas Pasir Pengaraian \\ e-mail: ciciliamelinda@upp.ac.id
}

\begin{abstract}
Critical thinking skills need to be instilled in the learning process in junior high schools. In this case, a teaching method that can improve students' critical thinking skills, namely the problem based learning method, is needed. The purpose of this study was to examine whether problem based learning method was able to improve the critical thinking skill of students in junior high school in the subjects of Social Sciences. The research method is quantitative. The research instrument used a test at the beginning and end of learning. The data collecting technique used test. The data analysis of this study used a partial test. The results showed that the problem based learning method had an influence on the critical thinking skills of students with $t$ table $3,902<t$ count 1.669 . Thus, there is an effect of the problem based learning method on the critical thinking skills of junior high school students.
\end{abstract}

Keywords: critical thinking skill, problem based learning, students

Received: 20 Februari 2021

Accepted: 12 Mei 2021

Published: 28 Juni 2021

\section{PENDAHULUAN}

Perkembangan teknologi informasi di dunia mengakibatkan perubahan dalam berbagai bidang kehidupan, termasuk perubahan di bidang pendidikan. Dunia pendidikan sangat erat kaitanya dengan pendidik karena tugas pendidik adalah mengajar, mendidik, dan melatih peserta didiknya agar menjadi individu yang berkualitas, terutama dalam hal berpikir. Kemampuan berpikir juga harus dikembangkan. Peserta didik diharapkan mampu mengembangkan potensi berpikir mereka menjadi berpikir kritis. Tujuan utama sekolah adalah membentuk kemampuan berpikir kritis peserta didik (Slavin dalam Karim \& Normaya, 2015). Kalelioğlu \& Gülbahar (2014) menjelaskan bahwa berpikir kritis juga diperlukan untuk mengetahui kebenaran informasi, sehingga dapat diketahui informasi tersebut bisa ditolak atau diterima. Agar peserta didik mampu berpikir kritis, perlu adanya usaha meningkatkan pembelajaran dengan menggunakan metode belajar yang mampu membantu peserta didik berpikir secara kritis dalam memecahkan 
permasalahan pada materi pembelajaran, termasuk pada Ilmu Pengetahuan Sosial (IPS).

Secara umum, pembelajaran yang dilaksanakan di Sekolah Menengah Pertama (SMP) di Rokan Hulu belum mampu melatih potensi berpikir kritis peserta didik. Pendidik lebih menekankan pada penghafalan fakta di kelas, sehingga siswa berada pada ranah kognitif yang cenderung berorientasi pada text book tanpa mampu berpikir, yaitu mengapa dan bagaimana suatu hal terjadi. Keterampilan berpikir kritis sangat penting dimiliki oleh peserta didik agar lebih terampil dalam menyusun sebuah bukti, memeriksa keakuratan sumber materi pembelajaran, atau membuat suatu keputusan dalam menyelesaikan permsalahan dalam proses pembelajaran. Oleh karena itu, berpikir kritis perlu dilatihkan pada peserta didik. Keterampilan berpikir kritis bisa dilatih melalui pembelajaran dengan metode problem based learning (PBL). Metode ini adalah pendekatan dalam pembelajaran yang memotivasi peserta didik untuk belajar bekerjasama dalam kelompok, mencari cara memecahkan masalah dalam belajar, mencari cara memecahkan masalah dalam kehidupan sehari hari di dunia nyata, serta mengembangkan keterampilan untuk menjadi pelajar mandiri (Akçay, 2009). Metode ini juga merupakan salah satu metode yang bisa diandalkan dan sangat efektif untuk pengajaran proses berpikir kritis. Sesuai dengan penelitian Ramlawati et al. (2017), pembelajaran dengan metode problem based learning mempengaruhi motivasi dan hasil belajar IPA siswa SMP. Metode pembelajaran problem based learning sangat membantu untuk memproses informasi dan menyusun ilmu tentang dunia sosial dan sekitarnya.

Berdasarkan hasil kunjungan lapangan dan wawancara di SMP di Rokan Hulu, peneliti menemukan pembelajaran IPS masih menekankan pada pemahaman kognitif berupa materi dan menghafal materi pelajaran untuk nanti diujikan dalam ujian tengah semester dan ujian akhir semester. Pembelajaran seperti ini akan sulit untuk mengembangkan keterampilan berpikir kritis karena kurangnya kesempatan yang diberikan pendidik dalam proses pemberian materi pelajaran di kelas. Proses pembelajaran menggunakan metode yang kurang memotivasi peserta didik dalam berpikir, sehingga mereka kurang mampu dalam menyampaikan pendapat maupun gagasannya ketika pembelajaran sedang berlangsung. Oleh karena itu, digunakan proses pembelajaran berbasis masalah, di mana metode ini mempunyai ciri-ciri yaitu permasalahan nyata sebagai konteks untuk para peserta didik belajar berfikir kritis dan keterampilan memecahkan masalah serta memperoleh pengetahuan dari permasalahan yang telah berhasil dipecahkan (Shoimin, 2014). Dalam pembelajaran ini, peserta didik akan terlibat dan secara aktif melakukan pengembangan kemampuan berpikir yang dimilikinya. Hal ini sesuai dengan pendapat Wee (dalam Amir, 2016: 13) yang menyebutkan bahwa ciri-ciri proses PBL yaitu "menunjang pembangunan kecakapan mengatur diri sendiri (selfdirected), kolaboratif, berpikir secara metakognitif, cakap menggali informasi." Berpikir kritis dapat dilihat sebagai seperangkat keterampilan yang menghasilkan

Jurnal Pendidikan IImu Sosial, Vol. 31, No.1, Juni 2021,

p-ISSN: 1412-3835; e-ISSN: 2541-4569 
dan memproses informasi dan keyakinan serta sebagai suatu kebiasaan yang menggunakan keterampilan tersebut untuk memandu perilaku (Scriven \& Paul dalam Defining Critical Thinking, n.d.).

Terdapat banyak penelitian yang sudah pernah dilakukan tentang keterampilan berpikir kritis dan problem based learning. Penelitian-penelitian tersebut menunjukkan bahwa model/metode problem based learning berpengaruh terhadap keterampilan berpikir kritis siswa, khususnya siswa SMP (Aswan et al., 2018; Yolanda, 2019; Afdareza et al., 2020). Meskipun sebenarnya terdapat beberapa prediktor yang mungkin juga mempengaruhi hubungan berpikir kritis dan PBL seperti usia, jenis kelamin, prestasi akademik, dan latar belakang pendidikan (Masek \& Yamin, 2011). Sesuai dengan pembahasan di atas, peneliti tertarik melakukan penelitian untuk melihat apakah metode pembelajaran problem based learning berpengaruh terhadap keterampilan berpikir kritis mata pelajaran IPS pada peserta didik kelas VIII SMP di Kabupaten Rokan Hulu.

\section{METODE PENELITIAN}

Penelitian ini adalah penelitian kuantitatif dengan menggunakan metode eksperimen semu karena dalam ilmu sosial penelitian sering bersifat kuasi di mana pengontrolan terhadap faktor yang diteliti tidak bisa dilakukan secara ketat. Menurut Siyoto \& Sodik (2015), tata cara pengambilan data yang digunakan dalam penelitian ini adalah tes di awal dan di akhir penelitian control group design, di mana pembagian kelas yang diberikan dan kelas yang tidak diberikan metode pembelajaran yang telah ditetapkan peneliti dilakukan secara acak. Kelompok yang diberikan metode pembelajaran yang ditetapkan dan kelompok yang tidak di berikan metode yang telah ditetapkan diberikan tes awal terlebih dahulu. Selanjutnya, pada kelas perlakuan diberikan pembelajaran metode problem based learning, sedangkan kelas yang tidak diberikan perlakuan diberikan pembelajaran dengan metode yang bervariasi, seperti ceramah, tanya jawab, dan kerja kelompok. Setelah diterapkan metode pada masing-masing kelas, baik kelas yang diberi perlakuan maupun kelas yang tidak diberikan perlakuan, maka dilakukan tes akhir. Post-test dilakukan untuk melihat dampak dari masing-masing metode yang diterapkan pada masing-masing kelas yang diberikan perlakuan dan kelas yang tidak diberikan perlakuan, sehingga diketahui apakah ada perubahan yang terjadi pada kelas yang diberi perlakuan metode problem based learning dan dapat membandingkannya dengan kelas yang menggunakan metode pembelajaran yang bervariasi. Sampel penelitian diambil secara acak dari beberapa kelas di SMPN 12 Tambusai Utara, seperti yang telah dijelaskan. Dari hasil acak, kelas yang akan diberikan perlakuan diperoleh sampel penelitian peserta didik di kelas VIIIB dan VIIIC dengan jumlah 30 peserta didik.

Penelitian ini dilakukan pada kelas VIII di SMPN 12 Tambusai Utara sebagai subjek penelitian yang terdiri atas dua kelas yakni kelas yang diberi perlakuan dan kelas yang tidak diberi perlakuan. Penelitian dilakukan pada bulan Juli sampai

Jurnal Pendidikan IImu Sosial, Vol. 31, No.1, Juni 2021,

p-ISSN: 1412-3835; e-ISSN: 2541-4569 
Oktober tahun ajaran 2019/2020. Data yang digunakan dalam penelitian ini adalah tes. Hasil tes akan dilihat validitas dan normalitasnya menggunakan SPSS 20. Setelah itu, dilakukan uji t dengan taraf sig 0,05. Jika nilai sig lebih besar dari 0,05, maka tidak terdapat dampak metode pembelajaran problem based learning terhadap keterampilan berpikir kritis peserta didik. Jika nilai sig lebih kecil dari 0,05 maka terdapat dampak metode pembelajaran problem based learning terhadap keterampilan berpikir kritis peserta didik.

\section{HASIL PENELITIAN DAN PEMBAHASAN}

Penerapan Rencana Pelaksanaan Pembelajaran (RPP) dalam Metode Problem Based Learning

Dalam penelitian ini, peneliti menggunakan RPP dengan metode pembelajaran bervariasi di kelas VIIIB di mana kelas ini tidak diberikan perlakuan, sedangkan peneliti menggunakan RPP problem based learning di kelas VIIIC yang diberikan perlakuan. Materi yang dipelajari yakni interaksi antarruang di negara-negara Asia Tenggara. Keterlaksanaan RPP dengan metode pembelajaran bervariasi di kelas yang tidak diberikan perlakuan yaitu memperoleh nilai sebesar 3,50 dalam ukuran baik. Keterlaksanaan RPP dengan menggunakan metode problem based learning mendapat nilai sebesar $80 \%$ yang digolongkan dalam kriteria baik. Kriteria ini sesuai dengan keterlaksanaan pendekatan pembelajaran menurut Riduwan (dalam Kurniasari \& Kusnan, 2018) yaitu rentang 81-100\% sangat baik, rentang 61-80\% baik, rentang 41-60\% sedang, dan rentang 21-40\% kurang, rentang 0-20\% sangat kurang. Dengan adanya keterlaksanaan RPP metode pembelajaran bervariasi dan metode problem based learning, maka dapat diketahui pembelajaran yang diterapkan dapat berpengaruh pada keterampilan berpikir kritis speserta didik di SMP N 12 Tambusai Utara.

\section{Keterampilan Berpikir Kritis Peserta Didik}

Tes uraian digunakan untuk melihat hasil dari keterampilan berpikir kritis peserta didik SMP N 12 Tambusai Utara. Tes ini terdiri atas lima soal. Dari lima soal tersebut didapatkan hasil keterampilan berpikir kritis peserta didik, yang kemudian diukur menggunakan tes di awal dan tes di akhir pembelajaran. Pada uji coba pertama di kelas yang tidak diberikan perlakuan yang menerapkan metode bervariasi, penguasaan konsep pada materi interaksi antar ruang di negara-negara Asia Tenggara sebelum digunakan metode bervariasi diperoleh hasil tes awal sebesar 56,75. Hal ini mencerminkan nilai yang rendah. Peserta didik kurang memahami materi. Setelah diterapkan metode pembelajaran bervariasi, nilai tes akhir peserta didik mulai meningkat yakni sebesar 76,25 , di mana nilai ini sudah tinggi. Hal ini dikarenakan pendidik hanya menjelaskan materi pembelajaran tanpa menghubungkan dengan permasalahan dan cara mengatasinya, di mana hal ini mampu membuat keterampilan berpikir peserta didik menjadi lebih terasah. Sebagai akibatnya, peserta didik hanya mampu memahami materi dengan

Jurnal Pendidikan IImu Sosial, Vol. 31, No.1, Juni 2021,

p-ISSN: 1412-3835; e-ISSN: 2541-4569 
mendengarkan penjelasan saja. Dapat ditarik kesimpulan bahwa metode bervariasi dapat menumbuhkan keterampilan berpikir kritis peserta didik, sehingga nilai yang diperoleh tinggi, yakni interpretasi $71,50<\mathrm{X} \leq 81,25$. Hal ini dapat dilihat pada tabel berikut.

Tabel 1.

Kriteria Kemampuan Berpikir Kritis

\begin{tabular}{cc}
\hline Interpretasi \% & Kategori \\
\hline $81,25<\mathrm{X} \leq 100$ & Sangat tinggi \\
$71,50<\mathrm{X} \leq 81,25$ & Tinggi \\
$62,50<\mathrm{X} \leq 71,50$ & Sedang \\
$43,75<\mathrm{X} \leq 62,50$ & Rendah \\
$0<\mathrm{X} \leq 43,75$ & Sangat rendah
\end{tabular}

Sumber: Setyowati (dalam Karim \& Normaya, 2015)

Pada uji coba kedua, kelompok yang diberikan perlakuan menggunakan metode problem based learning dapat dilihat bahwa hasil penguasaan konsep materi interaksi antarruang di negara-negara Asia Tenggara sebesar 68 yang berarti sedang. Hal ini berarti peserta didik kurang memahami materi yang dijelaskan pendidik. Upaya yang dilakukan untuk melatihkan keterampilan berpikir kritis peserta didik adalah menggunakan metode problem based learning. Setelah diberikan perlakuan, peserta didik memperoleh nilai tes akhir sebesar 86 yang termasuk sangat tinggi. Metode problem based learning ini mampu menumbuhkan keterampilan berpikir kritis peserta didik. Sesuai dengan kriteria ketuntasan minimal (KKM) sebesar 75, maka keterampilan berpikir kritis peserta didik yang menggunakan metode problem based learning lebih bagus dibandingkan dengan yang menggunakan metode pembelajaran bervariasi. Hal ini dapat dilihat dari hasil tes akhir dengan rata-rata sebesar 86 pada peserta didik yang menggunakan metode problem based learning, sedangkan hasil tes akhir peserta didik yang menggunakan metode pembelajaran bervariasi yakni sebesar 78,25.

Penelitian yang telah dilakukan adalah penelitian oleh Almukarram et al. (2016) yang menggunakan metode jigsaw untuk meningkatkan berpikir kritis siswa pada mata pelajaran IPA. Model ini juga cocok meningkatkan interaksi antarsiswa dan meningkatkan rasa tanggung jawab. Berdasarkan paparan di atas, model pembelajaran kooperatif tipe jigsaw dapat meningkatkan hasil belajar peserta didik dan sekaligus dapat meningkatkan berpikir kritis peserta didik.

Usaha peneliti dalam mengasah kemampuan berpikir kritis peserta didik yaitu dengan mengembangkan metode pembelajaran yang bervariasi karena tidak ada metode pembelajaran yang sempurna, sehingga diperlukan variasi metode pembelajaran yang menumbuhkan kemahiran berpikir. Penelitian ini menggunakan dua metode pembelajaran yakni metode bervariasi dan metode problem based learning. Sebelum peneliti menerapkan metode problem based learning, peneliti menjelaskan langkah-langkah metode tersebut agar dalam proses pemberian

Jurnal Pendidikan IImu Sosial, Vol. 31, No.1, Juni 2021,

p-ISSN: 1412-3835; e-ISSN: 2541-4569 
materi peserta didik sudah paham metode pembelajaran yang digunakan. Peneliti juga menjelaskan kepada peserta didik bahwa dengan metode pembelajaran problem based learning peserta didik akan mendapatkan banyak informasi tentang materi yang diajarkan pendidik dan materi lain yang didapatkan dari hasil memberikan solusi dari permasalahan yang ada dalam materi interaksi antar ruang di negara-negara di Asia Tenggara.

Penelitian ini dilakukan pada dua kelas di SMP N 12 Tambusai Utara yaitu kelas VIIIC sebagai kelas untuk diterapkan perlakuan dan kelas VIIIB sebagai kelas yang tidak diterapkan perlakuan. Kelas VIIIC sebagai kelas yang diterapkan perlakuan menggunakan metode problem based learning yang melibatkan 30 peserta didik. Hasil keterampilan berpikir kritis peserta didik diperoleh dari nilai tes awal dan tes akhir. Soal dalam tes ini yaitu berupa lima soal uraian dari materi interaksi antar ruang di negara-negara Asia Tenggara. Nilai tes awal diperoleh sebelum penerapan metode pembelajaran, sedangkan nilai tes akhir diperoleh dari sesudah penerapan metode pembelajaran problem based learning. Uji persyaratan dilakukan untuk mengetahui ada tidaknya pengaruh metode pembelajaran problem based learning dalam mata pelajaran IPS. Selain itu, uji ini juga untuk mengetahui apakah data berdistibusi normal atau tidak dan apakah data bersifat homogen atau tidak homogen (lihat Tabel 2 dan Tabel 3).

Tabel 2.

Daftar Uji Normalitas Nilai Pre-Test Kelas Eksperimen dan Kelas Kontrol

\begin{tabular}{clccc}
\hline No & Kelas & Lhitung $_{\text {Ltabel }}$ & Kriteria \\
\hline 1 & Eksperimen & 0,122 & 0,149 & Normal \\
2 & Kontrol & 0,111 & 0,149 & Normal \\
\hline
\end{tabular}

Sumber : Pengolahan data Primer (2020)

Tabel 3.

Uji Homogenitas Nilai Pre-Test Kelas Eksperimen dan Kelas Kontrol

\begin{tabular}{lcc}
\hline \multicolumn{1}{c}{ Sumber Variasi } & Kelas Eksperimen & Kelas Kontrol \\
\hline Jumlah Nilai & 1.096 & 1.196 \\
n (jumlah siswa) & 35 & 35 \\
$\bar{X}$ (nilai rata-rata) & 31,31 & 34,17 \\
$\left(\mathrm{~S}^{2}\right)$ Varians & 154,81 & 149,96 \\
$(\mathrm{~S})$ Standar Deviasi & 12,36 & 12,25 \\
\hline
\end{tabular}

Sumber: Pengolahan Data Primer (2020)

Berdasarkan Tabel 2 dan Tabel 3, diketahui nilai signifikasi (sig.) untuk semua varian yang diteliti adalah normal dan homogen. Oleh karena itu, dapat diambil kesimpulan bahwa data penelitian yang sudah dilaksanakan adalah berdistribusi normal. Setelah dilakukan uji prasyarat, kemudian dilakukan pula uji hipotesis. Data untuk menguji hipotesis adalah nilai post-test. Hipotesis nilai post-test untuk mengetahui ada tidaknya pengaruh metode problem based learning terhadap keterampilan berpikir kritis peserta didik. Oleh karena itu, peneliti menggunakan rumus t-test dalam pengajuan hipotesis kemampuan akhir yaitu:

Jurnal Pendidikan IImu Sosial, Vol. 31, No.1, Juni 2021,

p-ISSN: 1412-3835; e-ISSN: 2541-4569 
Ho: $\mu_{1} \leq \mu_{2}$ : Artinya pembelajaran IPS dengan metode pembelajaran problem based learning tidak berpengaruh terhadap keterampilan berpikir kritis siswa kelas VIII SMP N 12 Tambusai Utara.

Ha: $\mu_{1} \neq \mu_{2}$ : Artinya pembelajaran IPS dengan metode pembelajaran problem based learning berpengaruh terhadap keterampilan berpikir kritis siswa kelas VIII SMP N 12 Tambusai Utara.

Berdasarkan Uji T diperoleh perhitungan pada Tabel 4 yaitu:

Tabel 4.

Hasil Hipotesis dengan menggunakan t-test

\begin{tabular}{cccccccc}
\hline & $\begin{array}{c}\mathbf{N} \\
\text { (jumlah } \\
\text { Siswa) }\end{array}$ & $\begin{array}{c}\overline{\boldsymbol{X}} \\
\text { Nilai } \\
\text { rata- } \\
\text { rata }\end{array}$ & $\begin{array}{c}\mathbf{S}^{2} \\
\text { Varian }\end{array}$ & $\begin{array}{c}\text { Standar } \\
\text { Deviasi }\end{array}$ & $\begin{array}{c}\text { Derajat } \\
\text { Kesukaran }\end{array}$ & $\boldsymbol{t}_{\text {hitung }}$ & $\boldsymbol{t}_{\text {tabel }}$ \\
\hline $\begin{array}{c}\text { Kelas } \\
\begin{array}{c}\text { Eksperimen } \\
\text { Kelas } \\
\text { Kontrol }\end{array}\end{array}$ & 35 & 75,54 & 104,26 & & & & \\
\hline
\end{tabular}

Sumber: Pengolahan Data Primer (2020)

Sesuai hasil pada Tabel 4, perhitungan hasil hipotesis menyatakan bahwa berdasarkan tes akhir kelas yang diberikan perlakuan yang menerapkan metode problem based learning diperoleh rata-rata 75,54 sedangkan untuk kelas yang tidak diberi perlakuan yang menggunakan metode pembelajaran bervariasi diperoleh rata-rata 65,71 . Adapun $\mathrm{dk}=35+35-2=68$ dan dengan taraf nyata $5 \%$ maka diperoleh $\boldsymbol{t}_{\text {tabel }}=1,669$. Dengan dasar pengambilan keputusan $\mathrm{H}_{0}$ ditolak apabila $\boldsymbol{t}_{\text {hitung }}<\boldsymbol{t}_{\text {tabel }}$ dan diterima $\mathrm{H}_{\mathrm{a}}$ apabila $\boldsymbol{t}_{\text {hitung }}>\boldsymbol{t}_{\text {tabel }}$. Karena $\boldsymbol{t}_{\text {hitung }}>\boldsymbol{t}_{\text {tabel }}=$ 3,902 > 1,669 maka dapat dinyatakan bahwa $\mathrm{H}_{0}$ ditolak dan $\mathrm{H}_{\mathrm{a}}$ diterima. Hal ini berarti bahwa keterampilan berpikir kritis dalam pembelajaran IPS peserta didik dipengaruhi oleh penggunaan metode pembelajaran problem based learning. Pembelajaran problem based learning mampu membuat peserta didik untuk beinteraksi dengan sesama. Selain itu, peserta didik termotivasi untuk mengetahui cara memecahkan permasalahan yang ada dalam materi pembelajaran sehingga kemampuan berpikir peserta didik lebih kritis dan bagus. Hasil ini sesuai dengan penelitian terdahulu yang berjudul pengaruh model pembelajaran problem based learning terhadap kemampuan pemecahan masalah Matematika peserta didik (Juliawan et al.. 2017). Penelitian-penelitian lainnya juga memiiki kesamaan hasil bahwa metode problem based learning dapat meningkatkan cara berfikir siswa, sehingga metode ini dapat menjadi pilihan guru dalam pembelajaran dikelas.

\section{KESIMPULAN}

Sesuai dengan telaah hasil penelitian dan analisis yang peneliti lakukan maka pembelajaran dengan metode problem based learning terbukti lebih mampu menguatkan keterampilan berpikir kritis peserta didik dibandingkan dengan 
pembelajaran dengan metode bervariasi. Hal ini dapat dilihat dari hasil nilai tes awal dan tes akhir yang sudah dilaksanakan dalam penelitian ini. Kelas yang tidak diberi perlakuan yang menggunakan metode pembelajaran bervariasi memperoleh nilai tes akhir sebesar 65,71 yang termasuk ke dalam nilai sedang. Sedangkan kelas yang diberi perlakuan dengan menggunakan metode problem based learning memperoleh nilai sebesar 78, 25 yang termasuk kedalam nilai tinggi. Dengan nilai yang lebih tinggi dari kelas yang tidak diberi perlakuan, maka dapat diambil kesimpulan bahwa pembelajaran dengan metode problem based learning lebih berpengaruh dalam membantu keterampilan berpikir kritis peserta didik pada materi interaksi antar ruang di negara-negara Asia Tenggara.

Saran untuk peneliti yang akan melakukan penelitian lanjutan yaitu sebaiknya peneliti dapat mempersiapkan semuanya dengan baik untuk meminimalisir kendala yang mungkin dapat terjadi. Hal ini dikarenakan peneliti mengalami kendala dalam pelaksanaan pembelajaran dengan metode problem based learning yaitu keadaan sarana dan suasana yang kurang membantu dalam menerapkan dan menumbuhkan keterampilan berpikir kritis peserta didik.

\section{DAFTAR PUSTAKA}

Afdareza, M. Y., Yuanita, P., \& Maimunah. 2020. Development of Learning Device Based on 21st Century Skill with Implementation of Problem Based Learning to Increase Critical Thinking Skill of Students on Polyhedron for Grade 8th Junior High School. Journal of Educational Sciences, 4(2), 273-284.

Akçay, B. 2009. Problem-based Learning in Science Education. Journal of Turkish Science Education, 6(1), 26-36.

Almukarram, A., Sarong, M. A., \& Apriana, E. 2016. Penerapan Model Pembelajaran Kooperatif Tipe Jigsaw Terhadap Peningkatan Kemampuan Berpikir Kritis Pada Konsep Pencemaran Lingkungan di SMA Negeri 12 Banda Aceh. BIOTIK: Jurnal Ilmiah Biologi Teknologi Dan Kependidikan, 4(1), 8-14. https://doi.org/10.22373/biotik.v4i1.1066.

Amir, M. T. 2016. Inovasi Pendidikan Melalui Problem Based Learning: Bagaimana Pendidik Memberdayakan Pemelajar di Era Pengetahuan. Jakarta: Kencana.

Aswan, D. M., Lufri, L., \& Sumarmin, R. 2018. Influence of Problem Based Learning on Critical Thinking Skills and Competence Class VIII SMPN 1 Gunuang Omeh, 2016/2017. IOP Conference Series: Materials Science and Engineering, 335, 15. https://doi.org/10.1088/1757-899X/335/1/012128.

Jurnal Pendidikan IImu Sosial, Vol. 31, No.1, Juni 2021,

p-ISSN: 1412-3835; e-ISSN: 2541-4569 
Defining Critical Thinking. n.d.. Defining Critical Thinking. The Foundation for Critical Thinking. https://www.criticalthinking.org/pages/defining-criticalthinking/766.

Juliawan, G. A., Mahadewi, L. P. P., \& Rati, N. W. 2017. Pengaruh Model Problem Based Learning (PBL) terhadap Kemampuan Pemecahan Masalah Matematika Siswa Kelas III. E-Journal PGSD Universitas Pendidikan Ganesha, 5(2), 1-10.

Kalelioğlu, F., \& Gülbahar, Y. 2014. The Effect of Instructional Techniques on Critical Thinking and Critical Thinking Dispositions in Online Discussion. Journal of Educational Technology \& Society, 17(1), 248-258. https://www.jstor.org/stable/10.2307/jeductechsoci.17.1.248.

Karim, K., \& Normaya, N. 2015. Kemampuan Berpikir Kritis Siswa dalam Pembelajaran Matematika dengan Menggunakan Model Jucama di Sekolah Menengah Pertama. EDU-MAT: Jurnal Pendidikan Matematika, 3(1), 92-104. https://doi.org/10.20527/edumat.v3i1.634.

Kurniasari, D., \& Kusnan. 2018. Implementasi Model Pembelajaran Probing Prompting Learning untuk Meningkatkan Hasil Belajar Siswa pada Mata Pelajaran Konstruksi Bangunan Kelas XI TGB di SMK Negeri 3 Jombang. Jurnal Kajian Pendidikan Teknik Bangunan, 2(2).

Masek, A. Bin, \& Yamin, S. 2011. The Effect of Problem Based Learning on Critical Thinking Ability: a Theoretical and Empirical Review. International Review of Social Sciences and Humanities, 2(1), 215-221. https://doi.org/10.1088/1742-6596/1157/4/042063.

Ramlawati, Yunus, S. R., \& Insani, A. 2017. Pengaruh Model PBL (Problem Based Learning) terhadap Motivasi dan Hasil Belajar IPA Peserta Didik. Jurnal Sainsmat, $6(1)$, $1-14$. http://ojs.unm.ac.id/sainsmat/article/download/6451/3684.

Shoimin, A. 2014. 68 Model Pembelajaran Inovatif dalam Kurikulum 2013. Yogyakarta: Ar-Ruzz Media.

Siyoto, S., \& Sodik, M. A. 2015. Dasar Metodologi Penelitian (Ayup (ed.)). Yogyakarta: Literasi Media Publishing.

Yolanda, F. 2019. The Effect of Problem Based Learning on Mathematical Critical Thinking Skills of Junior High School Students. Journal of Physics: Conference Series, 1397, 1-7. https://doi.org/10.1088/1742-6596/1397/1/012082. 